\title{
BELARUSIAN-NORWEGIAN COOPERATION ON THE ISSUE OF UN REFORM: CURRENT STATE AND PROSPECTS
}

\author{
D. V. LUZAN, S. F. SVILAS \\ Belarusian State University, \\ Minsk, Republic of Belarus
}

\begin{abstract}
The article examines one of the most pressing problems of modern world politics, which is the reform of the United Nations that is studied in the context of regional cooperation of the member states and its possible intensification in this area. Based on the analysis of diplomatic documents introduced into scientific circulation for the first time, a detailed description of the current state and prospects of cooperation between Norway and Belarus in the direction of reforming the UN is given.

Recently, there has been noticed a significant intensification of interaction between the two countries in various spheres of public life both at the European and global levels (consultations between the ministries of foreign affairs and the dialogue of their leaders, the growth of trade turnover, the exchange of technologies, the development of tourism). That stimulates the activities of diplomatic missions of Norway and Belarus to the UN, aimed at adapting and updating the work of the Organization in the light of new trends and processes in international life.

The key directions of the UN institutional reform, according to which it is possible to implement the Belarusian-Norwegian cooperation in the studied area, include the Security Council, the General Assembly, the Economic and Social Council, the Human Rights Council, the institute of peacekeeping. Twenty initiatives supported by Minsk and Oslo were considered, which could become the basis for cooperation in this direction. It is emphasized that the reform of the Security Council is most likely to become a starting point for fruitful interaction. At the same time, it will be possible to speak about the significance of steps to deepen it only if at least ten mutually complementary initiatives are implemented. The conditions for realizing the potential of cooperation have been determined as well; they include the creation of a developed legal framework for bilateral relations, their transfer to the level of embassies, the accession of the Republic of Belarus to the ACT Group of which Norway is a member.
\end{abstract}

Keywords: post-bipolar system of international relations; globalization; multilateral diplomacy; UN reform; regional cooperation; foreign policy and diplomacy of Norway; foreign policy and diplomacy of Belarus; Belarusian-Norwegian cooperation. 
For citation: Luzan D., Svilas S. (2020) Belarusian-Norwegian cooperation on the issue of UN reform: current state and prospects. In: Actual problems of international relations and global development : collection of scientific papers. Minsk, Vol. 8, p. 134-146. https://doi.org/10.33581/2311-9470-2020-8-134-146

Introduction. In the twenty-first century, when the contradictory process of globalization continues to intensify the international community is particularly concerned about the prospects of the United Nations considering it as an integral element of the modern system of international relations and global security. At the beginning of the XXI century, many states, supporting the trend towards polycentrism in the conditions of the US hegemony, expressed discontent with the declining role of the UN in international relations, and raised the question of a comprehensive reform of the Organization in order to strengthen its authority and influence in the world. Since then, the revitalization of the UN has been occupying an important place in the foreign policy of many states being defined as one of the priorities of world politics.

An intrinsic condition for the modernization of the United Nations is supposed to be the qualitative improvement of regional cooperation both at the level of country teams at headquarters (representative offices and delegations to forums) and at the level of regional organizations. The result of bilateral inter-state cooperation and joint efforts to strengthen and update the work of the UN can be the modification of ways out of the current crisis for the better when the number of critics of the post-1991 world order is constantly growing.

In this regard, considering the possibilities of cooperation on the issue of UN reform can open up new horizons for Belarusian-Norwegian cooperation, and bring relations between Minsk and Oslo to a qualitatively new level.

The purpose of the study is toreveal and assess the prospects of interstate cooperation between Norway and Belarus in the direction of the United Nations reform.

The objectives of the study are to characterize and compare the approaches of Belarus and Norway to the UN reform, to assess the possibilities of Belarusian-Norwegian cooperation on the organization's modernization, and to suggest measures to strengthen cooperation between Minsk and Oslo in this area.

The chronological framework of the study covers the period of the second half of the 2010 smarked by a significant intensification of cooper- 
ation between Belarus and Norway in different spheres of public life, both at the European and global levels. An actively promoted format of political dialogue in recent years has been consultations between the foreign ministries of the two countries ${ }^{1}$, there has taken place a regular dialogue between the foreign ministers of the states ${ }^{2,3}$, including in the framework of the $\mathrm{UN}^{4}$, significant progress has been made in the field of trade, economy and technology exchange ${ }^{5}$. At the same time, Minsk and Oslo have emphasized the need for further participation in the development of multilateral diplomacy. The studied aspect of inter-state cooperation has been repeatedly discussed in the framework of the joint Belarusian-Norwegian dialogue 6,7 .

The relevance of the study is determined by the importance of the discussion on the ways to increase the effectiveness of the UN, the active development of the Norwegian-Belarusian relations in the context of global relations, as well as the insufficient development of the issue in historiography. For this reason, the research is based mainly on information gathered from primary sources including official reports of meetings of UN bodies and speeches of Belarusian and Norwegian diplomats from the UN rostrum stored in UN digital resources, as well as publications on the websites of the foreign ministries of the two states.

Research methods. When conducting the research, the systematic, value, macro- and microsociological approaches were applied, there were used both general scientific (analysis, synthesis, comparison, generalization, induction, deduction) and special methods (institutional, structural and functional, analysis of political and diplomatic discourse).

The object of the research is the foreign policy of the Kingdom of Norway and the Republic of Belarus at the present stage.

\footnotetext{
${ }^{1}$ Deputy Minister of Foreign Affairs of Belarus O. Kravchenko visits Norway (2020). In: Ministry of Foreign Affairs of the Republic of Belarus. URL: http://mfa.gov.by/en/press/ news_mfa/bf1f6a1602441349.html (accessed 18.08.2020).

${ }^{2}$ Belarusian, Norwegian Foreign Ministers meet in New York (2019) In: Website of The Embassy of the Republic of Belarus in the Kingdom of Sweden. URL: http://sweden.mfa.gov.by/en/embassy/news/b41d465fd1127bb9.html (accessed 2020 August 18).

3 Belarus, Norway discuss bilateral cooperation, interaction in UN (2020) In: BELTA. URL: https://eng.belta.by/politics/view/belarus-norway-discuss-bilateral-cooperation-interaction-in-un130097-2020/ (accessed 2020 August 18).

${ }^{4}$ See 2 .

${ }^{5}$ See 1.

${ }^{6}$ See 1.

${ }^{7}$ See 3 .
} 
The subject of the research is the activity of the diplomatic missions of Norway and Belarus in the UN aimed at adapting and updating the work of the Organization in the light of new trends and processes in international life (initiatives, proposals, projects and their content).

Literature review. The issue of $\mathrm{UN}$ reform as a whole is covered quite well in historiography. In the Russian scientific community, recognized experts on this issue are V. Zaemskiy ${ }^{8}$, L. Grishaeva ${ }^{9}$, A. Nikitin ${ }^{10}$. In Western historiography the problem has been raised by Edward C. Luck $^{11}$, Thomas G. Weiss ${ }^{12}$ and others. Nevertheless, the approaches of some states, in particular Belarus and Norway, to UN reform are clearly not sufficiently represented.

Concerning Belarus' approaches to UN reform they were partly examined by a career diplomat A. Sychev in the article "Respublika Belarus' i OON [the Republic of Belarus and the UN]" [1]. Among the Belarusian priorities, he highlighted the adaptation of the Security Council to modern

\footnotetext{
${ }^{8}$ Zaemskiy, V. (2009) Reformy OON i mirotvorchestvo [The UN reform and peacekeeping]: the Dissertation of Doctor of Sciences in Politics. Moscow, $352 \mathrm{p}$.

Zaemskiy, V. (2011) Komu nuzhna reforma OON: v interesah vseh i kazhdogo [Who needs a reform of the United Nations: in everyone's interest]. - Moscow, $296 \mathrm{p}$.

${ }^{9}$ Grishaeva, L. (2008) Genezis uchastija Rossii v dejatel'nosti OON: prioritetnye napravlenija (1945 - 2007) [Genesis of Russia's participation in the UN: priority directions (1945-2007)]: the Dissertation of Doctor of Sciences in History. Moscow, $456 \mathrm{p}$.

Grishaeva, L. (2007) Rossija i OON: istorija i sovremennost' [Russia and the UN: history and modernity]. Moscow, $500 \mathrm{p}$.

${ }^{10}$ Nikitin, A. (2017) Mezhdunarodnye konflikty: vmeshatel'stvo, mirotvorchestvo, uregulirovanie: Uchebnik [International conflicts: intervention, peacemaking, settlement: Textbook]. Moscow, $384 \mathrm{p}$.

Nikitin, A. (2016) Novaja sistema otnoshenij velikih derzhav XXI veka: «koncert» ili konfrontacija? [New system of relations between the great powers of the XXI century: "concert" or confrontation?] In: Polis, Vol. 1, p. 44-59.

Nikitin, A. (2016) Mirotvorchestvo OON: obnovlenie principov, reformirovanie praktiki [UN peacekeeping: an update of principles, reforming practice]. In: World Economy and International Relations, Vol. 3, p. 16-26.

11 Thomas G. Weiss. (2003) The Illusion of UN Security Council Reform. In: The Washington Quarterly, No 26, p. 147-161.

Weiss T. G., Young K. E. (2005) Compromise and Credibility: Security Council Reform? In: Security Dialogue, Vol. 36, p. 146-168.

Thomas G. Weiss, Sir Brian Urquhart. (2013) What's Wrong with the United Nations and How to Fix it. Wiley, 288p.

${ }^{12}$ Luck E. C. (2006) The Survivors: The United States and the United Nations in Troubled Times. In: American Foreign Policy Interests, Vol. 28, p. 293-296.

Edward C. Luck. (2003) Reforming the United Nations: Lessons from a History in Progress. In: New Haven: Academic Council on the UN System, 74 p.
} 
realities, the revitalization of the General Assembly and work on clarifying the provisions of the UN Charter.

The position of Belarus on the UN reform was analyzed by A. Tikhomirov in the monograph "Vneshnjaja politika Respubliki Belarus' (1991-2015) [Foreign policy of the Republic of Belarus (1991-2015)]” [2], as well as in the article "Vzaimodejstvie Respubliki Belarus' i OON (1991-2015) [Interaction of the Republic of Belarus and the UN (19912015)]" [3].The expert expressed the opinion that at the beginning of the XXI century, Belarus relied on rationalizing the activities of the central UN bodies by giving them "adequate opportunities for the effective implementation of the Charter goals and objectives".

Norwegian approaches to UN reform have not been studied in academic circles. The existing assessment of the potential and proposals of the Norwegian side is mainly contained in specialized reports of the Norwegian Ministry of Foreign Affairs ${ }^{13}$.

Thus, the historiography lacks a description of the current state of Belarusian-Norwegian relations and an assessment of their potential, including on the issue of the UN reform.

Results of the research. The study revealed that the key areas of institutional reform of the UN considered by the Norwegian side are the reform of the Security Council, modernization of the General Assembly, the Economic and Social Council, the Human Rights Council, as well as peacekeeping. This mainly coincides with the directions of the UN reform being developed by the Republic of Belarus, except that the Belarusian diplomacy also has a well-formed position on the issue of the UN Secretariat reform.

\footnotetext{
${ }^{13}$ Prosjektrapport. FN 2015. Hvordan kan Norge bidra til reform og styrking av FN? [Project report. UN 2015. How Can Norway contribute to the reform and strengthening of the United Nations?] (2011). In: Utenriksdepartementet. Oslo, 124 p. URL: https://www.regjeringen.no/globalassets/upload/ud/vedlegg/fn/fnrapport_2011nett.pdf(accessed 2020 November 14). (In Norw.)

Aktuelle FN-spørsmål. FNs 60.generalforsamling. Høsten 2005 [Current UN questions. UN 60. General meeting. Autumn 2005] (2005). In: Utenriksdepartementet. Oslo, 165 p. URL: https://www.regjeringen.no/globalassets/upload/kilde/ud/bro/2005/0119/ddd/pdfv/255233fnaktuell05.pdf(accessed 2020 November 14). (In Norw.) Meld. St. 33 (2011-2012). Melding til Stortinget. Norge og FN: Felles framtid, felles løsninger [Meld. St. 33 (2011-2012). Message to parliament. Norway and the United Nations: Joint future, joint solutions] (2012). In: Utenriksdepartementet. Oslo, 117 p. URL: https://www.mynewsdesk.com/material/document/23252/download?resource_type=resource_docu ment (accessed 2020 November 14). (In Norw.)
} 
The study found that 20 initiatives supported simultaneously by the Kingdom of Norway and the Republic of Belarus can become the foundation for Norwegian-Belarusian cooperation in the framework of UN reform (see table 1). At the same time, significant steps to deepen such cooperation can be taken if more than 10 mutually complementary initiatives are implemented on a joint basis (these are the initiatives supported by either of the parties, but being estimated to meet the interests of the other party). It should be noted that the largest number of them was recorded in the analysis of Norwegian and Belarusian approaches to the reform of the UN Security Council. Such a situation may most likely indicate that the reform of this central UN body will serve as a starting point for the joint expression of the will of the states in the process of reforming the organization as a whole.

Table 1. Common and mutually complementary initiatives of the Republic of Belarus and the Kingdom of Norway in the UN reform

\begin{tabular}{|c|c|c|c|}
\hline & $\begin{array}{c}\text { Mutually } \\
\text { complementary }\end{array}$ & Belarus & Norway \\
\hline $\begin{array}{l}\text { Clarification of UN funding issues } \\
\text { completeness, unconditionality and } \\
\text { compliance with time limits by states in } \\
\text { fulfilling financial obligations }\end{array}$ & MC & + & + \\
\hline $\begin{array}{l}\text { priority of budget financing of UN } \\
\text { activities over sponsorship }\end{array}$ & MC & + & \\
\hline $\begin{array}{l}\text { consideration of the business segment as a } \\
\text { partner in financial matters }\end{array}$ & & + & + \\
\hline $\begin{array}{l}\text { Clarification of issues of interaction between the } \\
\text { GA and the SC }\end{array}$ & & + & + \\
\hline$-\quad$ legal support of the process & & + & + \\
\hline Updated and more effective UN country teams & & + & + \\
\hline $\begin{array}{l}\text { Development of cooperation with regional } \\
\text { organizations }\end{array}$ & & + & + \\
\hline$-\quad$ including Groups of Friends & & + & + \\
\hline$-\quad$ special attention to the African Union & & + & + \\
\hline $\begin{array}{l}\text { The expansion of UN cooperation with civil } \\
\text { society }\end{array}$ & & + & + \\
\hline $\begin{array}{l}\text { The UN Security Council reform } \\
\text { a more transparent, inclusive and } \\
\text { accountable body }\end{array}$ & & + \\
\hline $\begin{array}{l}\text { expansion so as to reflect the realities of } \\
\text { non-permansion in both the permanent and the }\end{array}$ & & + & + \\
\hline special attention to the region of Africa & & + & + \\
\hline
\end{tabular}




\begin{tabular}{|c|c|c|c|}
\hline $\begin{array}{l}\text { - } \begin{array}{l}\text { special attention to the Eastern Europe } \\
\text { region, as well as other underrepresented } \\
\text { regions }\end{array} \\
\end{array}$ & $\mathrm{MC}$ & + & \\
\hline $\begin{array}{l}-\quad \begin{array}{l}\text { expanding the representation of developing } \\
\text { states }\end{array} \\
\end{array}$ & $\mathrm{MC}$ & & + \\
\hline $\begin{array}{l}\text { more opportunities for small states to be } \\
\text { elected }\end{array}$ & $\mathrm{MC}$ & & + \\
\hline - the principle of fiscal neutrality & $\mathrm{MC}$ & + & \\
\hline $\begin{array}{l}\text { Strengthening the role of the President and Vice- } \\
\text { presidents of the GA }\end{array}$ & & + & + \\
\hline - financial and technical assistance & $\mathrm{MC}$ & + & \\
\hline - providing a better "institutional memory" & & + & + \\
\hline $\begin{array}{l}\text { additional powers, including in informal } \\
\text { negotiations to move directly to the topic } \\
\text { of negotiations instead of general } \\
\text { discussion }\end{array}$ & $\mathrm{MC}$ & & + \\
\hline $\begin{array}{l}\text { Optimizing the election process for the Secretary- } \\
\text { General }\end{array}$ & & + & + \\
\hline $\begin{array}{l}\text { - achieving greater transparency in the } \\
\text { process }\end{array}$ & & + & + \\
\hline $\begin{array}{l}\text { Optimizing the interaction of the ECOSOC with } \\
\text { international economic organizations, including } \\
\text { the World Trade Organization (WTO) }\end{array}$ & & + & + \\
\hline $\begin{array}{l}\text { - reducing politicization of approaches to } \\
\text { cooperation with developing countries }\end{array}$ & $\mathrm{MC}$ & + & \\
\hline $\begin{array}{l}\text { - solving the problem of monopolization of } \\
\text { rights to join the WTO }\end{array}$ & $\mathrm{MC}$ & + & \\
\hline $\begin{array}{l}\text { - developing a joint WTO-UN strategy to } \\
\text { assist countries affected by conflict, } \\
\text { instability or violence }\end{array}$ & $\mathrm{MC}$ & & + \\
\hline Achieving gender equality within the UN & & + & + \\
\hline Peacekeeping reform & & + & + \\
\hline - more goal-oriented missions & & + & + \\
\hline
\end{tabular}

Source: authoring on the basis of the reports of the Ministry of Foreign Affairs of Norway ${ }^{14}$, the official website of the Ministry of Foreign Affairs of the Republic of Belarus ${ }^{15}$, the UN Digital Library ${ }^{16}$ and the United Nations PaperSmart ${ }^{17}$.

It was found out that the potential of bilateral cooperation in the framework of UN reform is not limited exclusively to mutually complementary initiatives. There is a host of proposals, on which only one of the

\footnotetext{
${ }^{14}$ See 13.

15 The official website of the Ministry of Foreign Affairs of the Republic of Belarus. URL: http://www.mfa.gov.by/en/ (accessed 2020 March 20).

${ }^{16}$ The United Nations Digital Library. URL: https://digitallibrary.un.org/ (accessed 2020 April 15).

${ }^{17}$ United Nations PaperSmart. URL: https://papersmart.unmeetings.org/en/(accessed 2020 May 5).
} 
two states has formed an opinion. Finding a compromise on such issues could significantly deepen Norwegian-Belarusian cooperation in the UN.

To illustrate, let us consider some aspects of the reform of the abovementioned Security Council. Thus, the Belarusian diplomacy has not previously expressed the need to update the rules on the use of the veto by permanent members of the Council. At the same time, the Norwegian side has formed its position on this issue: "It must be recognised that in instances today where the Council fails to live up to its Charter obligations, a main source of this inability to act is the veto" 18 .

In the framework of the research, an inversion of this example was found as well. The Republic of Belarus supports the creation of a clear mechanism for the introduction and lifting of sanctions, as well as countering their impact on non-involved states. According to the position of the Belarusian diplomacy, the "humanitarian limits" of sanctions must be determined and the likely consequences for third countries and the civilian population, especially the most vulnerable groups, must be calculated ${ }^{19}$. Nonetheless, when studying the Norwegian approaches to the reform of the UN Security Council the formulated position on the issue of sanctions was not found.

This example clearly demonstrates the potential of BelarusianNorwegian cooperation in reforming the Security Council, as well as the UN system as a whole. Reaching an agreement and finding common ground on a wealth of such issues could greatly contribute to bringing Norway and Belarus closer together at both regional and global levels.

Along with that, there are certain contradictions in the positions of states in relation to some UN bodies (in particular, the Human Rights Council). Historically, there has been a "split" between Western and Eastern interpretations of the concept of "human dignity", which underlies the understanding of human rights. Western states (primarily, the United States, Western European countries, and other developed countries) focus on civil and political rights, while the opposition bloc (in particular, Russia, Belarus, and China) recognize the socio-economic rights of citizens as a basis [4]. Meanwhile, it is the Western interpretation that largely determines the work of the HRC, which explains a number of criticisms to this body from Eastern States.

\footnotetext{
${ }^{18}$ See 17.

${ }^{19}$ See 16.
} 
Overall, the thesis about the importance of real respect for human rights throughout the world fully meets the interests of both countries. In addition, the issue of gender equality is of paramount importance for both Belarus and Norway. That is why both states highlight in their positions the crucial importance of achieving gender balance within the UN system ${ }^{20,21}$.

If to sum up, it is possible to conclude that at the present stage and while maintaining the current dynamics of development of NorwegianBelarusian relations in the near future, the vector of United Nations reform can become one of the key elements of cooperation between the two countries. However, such cooperation cannot be conducted without proper preparation. In this regard, it is deemed expedient to initiate three practically implementable steps that make it possible to set up to the full the interaction between Norway and Belarus.

First, as has been repeatedly noted in the framework of interdepartmental consultations, one of the priorities of bilateral cooperation, for the time being, is the creation of a developed legal framework ${ }^{22,23}$. In this context, it would be apt to pay special attention to the problem of UN reform and the joint capabilities of states. The development of a legal framework that takes into account such opportunities and promotes their practical implementation would be a significant step towards long-term and fruitful cooperation in this area.

Secondly, the transfer of bilateral relations to the level of embassies will be of help to strengthen cooperation. At the moment, relations are established at the level of the concurrent embassies: the role of the Embassy of Belarus to Norway performs the Embassy of Belarus in Sweden, while the role of the Royal Norwegian Embassy to Belarus performs the Royal Norwegian Embassy in the Ukraine. Taking the aforementioned step, in addition to the actual confirmation of the intentions to further develop inter-state cooperation, will allow the embassies to become a kind of coordination centres.

Finally, the third significant step towards successful cooperation in implementing the UN reform can be the accession of the Republic of Bela-

\footnotetext{
20 See 17

$2165^{\text {th }}$ session of the General Assembly of the United Nations. In: the United Nations. URL: https://www.un.org/en/ga/65/ (accessed 2020 August 18).

22 See 1.

${ }^{23}$ See 3.
} 
rus to the ACT (accountability, coherence and transparency) Group, of which Norway is a member. This group includes 25 small and mid-sized countries that are focusing on reforming the UN Security Council, primarily in its current composition. Even now, there are prerequisites for Belarus to consider the possibility of joining the ACT Group:

- of the eleven key measures proposed by the inter-state association, $45 \%$ is directly or indirectly in the interests of the Belarusian side (in the rest, the position has not been formed yet, which leaves a space for potential collaboration);

- of the five priorities of the association, $40 \%$ is Belarus' priorities as well in the reform of the Security Council (in respect of the others the situation is identical to the situation with the measures) $24,25,26,27$.

Discussion of the results. The historiography does not include research and publications on cooperation between Belarus and Norway in the field of UN reform.

In order to fill this gap, the source base was created and analyzed then which allowed identifying the key initiatives and proposals of both sides in the direction of reforming the Organization and comparing them, that, by and large, made it possible to state the existence of a significant potential for interstate cooperation.

In the future, the implementation of the proposed steps to enhance cooperation will increase its effectiveness, establish a truly fruitful dialogue on the reform of the United Nations and significantly strengthen bilateral relations between countries.

Conclusion. Thus, the study revealed favorable prospects for cooperation between Belarus and Norway in the field of UN reform, which is based on more than 20 common initiatives. The Belarusian-Norwegian dialogue will primarily be stimulated by the joint implementation of more than 10 complementary initiatives, as well as the discussion of a range of issues on which only one of the parties has formed an opinion to date.

\footnotetext{
${ }^{24}$ See 15.

${ }^{25}$ See 16.

${ }^{26}$ See 17.

${ }^{27}$ Factsheet. The Accountability, Coherence and Transparency (ACT) Group (2019). In: Eidgenössisches Departement für auswärtige Angelegenheiten (EDA) der Schweizerische Eidgenossenschaft. URL: https://www.eda.admin.ch/dam/eda/en/documents/aussenpolitik/internationaleorganisationen/20190910-factsheet-act_EN.pdf (accessed 2020 August 27).
} 
There were also identified some difficulties that hinder the transition of relations between the two countries to a new level. This primarily concerns various approaches to the interpretation (definition) of the category of "human dignity" which is one of the starting points in the discussions of the UN Human Rights Council. At the same time, Belarus and Norway emphasize the need for real respect for human rights, which is confirmed, in particular, by their mutual desire to achieve gender balance within the system of UN bodies.

Thus, while maintaining the dynamics of relations between Norway and Belarus observed over the past five years, cooperation in the UN reform vector can take an important place in the interaction of the two states. In order to move to partnership relations as soon as possible, Minsk and Oslo should take the following steps:

- first, to build a legal framework for bilateral cooperation, taking into account cooperation in the direction of UN reform;

- second, to raise the status of relations to the level of embassies instead of concurrent embassies;

- third, it is advisable for Minsk to consider joining forces with the ACT Group, the prerequisites for which already exist.

It is strongly believed that the progressive development of the Belarusian-Norwegian dialogue, especially within the UN framework, will bring the friendly peoples of Norway and Belarus closer together.

\section{References}

1. Sychov, A. (2006) Respublika Belarus' i OON [The Republic of Belarus and the UN]. In: Diplomatic Yearbook-2005. Collection of papers. Moscow, p. 244-268. (In Russ.)

2. Tihomirov, A. (2017) Vneshnjaja politika Respubliki Belarus' (1991-2015 gg.) [Foreign policy of the Republic of Belarus (1991-2015)]. Minsk, 208 p. (In Russ.)

3. Tihomirov, A. (2015) Vzaimodejstvie Respubliki Belarus' i OON (1991-2015 gg.) [Interaction between the Republic of Belarus and the UN]In: Actual problems of international relations and global development : collection of scientific papers. Minsk, Vol. 3, p. 261-276. (In Russ.)

4. Boyashov, A. (2019) Potencial Sojuznogo gosudarstva v sisteme OON [The Potential of the Union State of Russia and Belarus in the UN System].In: Contemporary Europe : social and political research journal. Moscow, Vol. 1, p. 138-147.(InRuss.)

Received: 16.11 .2020$. 
About authors: Daniil V. Luzan - student of the Faculty of International Relations of the Belarusian State University, participant of competitions and projects on UN issues; e-mail: fmo.luzanDV@bsu.by;

Svetlana F. Svilas - Doctor of Sciences in History, Professor of the Department of International Relations of the Belarusian State University; e-mail: svilas@tut.by.

DOI: $10.33581 / 2311-9470-2020-8-134-146$

\title{
БЕЛОРУССКО-НОРВЕЖСКОЕ СОТРУДНИЧЕСТВО В ОБЛАСТИ РЕФОРМИРОВАНИЯ ООН: СОСТОЯНИЕ И ПЕРСПЕКТИВЫ
}

\author{
Д. В. ЛУЗАН, С. Ф. СВИЛАС \\ Белорусский государственный университет \\ Минск, Республика Беларусь
}

В статье рассматривается одна из наиболее актуальных проблем современной мировой политики - реформа Организации Объединенных Наций, которая исследуется в контексте регионального сотрудничества государствчленов и его возможной интенсификации в этой области. На основе анализа дипломатических документов, впервые вводимых в научный оборот, дана развернутая характеристика современного состояния и перспектив сотрудничества Норвегии и Беларуси в направлении реформирования ООН.

Отмечается значительная активизация взаимодействия двух стран в различных сферах общественной жизни как на европейском, так и на глобальном уровнях (консультации между министерствами иностранных дел и диалог их руководителей, рост торгового оборота, обмен технологиями, развитие туризма), что стимулирует деятельность дипломатических миссий Норвегии и Беларуси в $\mathrm{OOH}$, направленную на адаптацию и актуализацию работы Организации в свете новых тенденций и процессов в международной жизни.

Выделены ключевые направления институциональной реформы $\mathrm{OOH}$, по которым возможна реализация белорусско-норвежского сотрудничества в исследуемой области: Совет Безопасности, Генеральная Ассамблея, Экономический и Социальный Совет, Совет по правам человека, институт миротворчества. Рассмотрены двадцать инициатив, поддерживаемых Минском и Осло, которые могут стать основой для сотрудничества в указанном направлении. Подчеркивается, что реформа Совета Безопасности с наибольшей вероятностью может стать отправной точкой для плодотворного взаимодействия. В то же время о значимости шагов по его углублению можно будет говорить лишь при 
условии реализации не менее десяти взаимодополняющих инициатив. Определены условия реализации потенциала сотрудничества: создание развитой договорно-правовой базы двусторонних отношений, перевод их на уровень посольств, присоединение Республики Беларусь к АCT Group.

Ключевые слова: постбиполярная система международных отношений; глобализация; многосторонняя дипломатия; реформа $\mathrm{OOH}$; региональное сотрудничество; внешняя политика и дипломатия Норвегии; внешняя политика и дипломатия Беларуси; белорусско-норвежское сотрудничество.

Образец цитирования: Luzan D., Svilas $S$. Belarusian-Norwegian cooperation on the issue of UN reform: current state and prospects // Актуальные проблемы международных отношений и глобального развития : сб. науч. ст. Минск, 2020. Вып. 8 С. 134-146. https://doi.org/10.33581/2311-9470-2020-8-134-146

Дата поступления статьи: 16.11 .2020$.

Авторы: Лузан Даниил Вячеславович - студент факультета международных отношений Белорусского государственного университета, участник конкурсов и проектов по проблематике OOH; e-mail: fmo.luzanDV@bsu.by;

Свилас Светлана Францевна - доктор исторических наук, профессор кафедры международных отношений Белорусского государственного университета; e-mail: svilas@tut.by. 